\title{
Active Tectonics of Gülbahçe Fault Zone (GBFZ) by Using Geomorphic Indices, İzmir Province, Western Anatolia, Turkey ${ }^{1}$
}

\author{
Berna ŞENGÖÇMEN GEÇKiN ${ }^{1,2 *}$, Hasan SÖZBiLiR ${ }^{2,3}$, Çağlar ÖZKAYMAK ${ }^{4,5}$, Mustafa SOFTA ${ }^{2}$ \\ ${ }^{1}$ Dokuz Eylül University, The Graduate School of Natural and Applied Sciences, izmir, Turkey. \\ ${ }^{2}$ Dokuz Eylül University, Department of Geological Engineering, Izmir, Turkey. \\ ${ }^{3}$ Earthquake Research and Implementation Center of Dokuz Eylül University, İmir, Turkey \\ ${ }^{4}$ Afyon Kocatepe University, Department of Geological Engineering, Afyonkarahisar, Turkey \\ ${ }^{5}$ Earthquake Research and Implementation Center of Afyon Kocatepe University, Afyonkarahisar, Turkey.
}

Sorumlu yazar* e-posta: berna.geckin@ogr.deu.edu.tr. ORCID ID: http://orcid.org/0000-0002-7804-2265 e-posta: hasan.sozbilir@deu.edu.tr ORCID ID: https://orcid.org/0000-0002-3777-4830 e-posta: activetectonics@gmail.com ORCIDID : https://orcid.org/0000-0002-0377-1324 e-posta: mustafa.softa@deu.edu.tr ORCID ID: https://orcid.org/0000-0001-5064-9260

Geliş Tarihi: 01.06.2021

Kabul Tarihi: 07.10.2021

\section{Abstract}

Keywords

Gülbahçe fault zone; Geomorphic indices;

Morphometric analysis;

Relative active

tectonics indices;

Geographic

Information Systems;

Western Anatolia

The Gülbahçe Fault Zone is a dextral strike-slip fault that extends for $\sim 24 \mathrm{~km}$ on land and $\sim 46 \mathrm{~km}$ under the sea, which consists of the significant southernmost active segments of İzmir Balıkesir Transfer Zone. In this study, the active tectonic behaviour of the Gulbahçe Fault Zone was evaluated by using of morphometric analysis of geomorphic indices. 30 sub-basins identified using ArcGIS ${ }^{\circledR 10.5}$ (ESRI). All sub-basins were calculated by using mountain-front sinuosity (Smf), valley-floor width to valley height ratio $(V f)$, basin asymmetry factor $(A f)$, basin shape indice $(B s)$, drainage density $(D d)$, and hypsometric integral $(H i)$ values. The obtained mean results of values are to define each sub-basin's relative tectonic activity (lat). The Smf, Vf, Af, Bs, Dd, and Hi values range from 1.05 to 1.33; from 0.21 to 4.09; from 25 to 77 ; from 1.03 and 3.06 ; from 0.28 to 0.67 , respectively. All the results were gathered under three classes, which sign high tectonics activity (Class 1 ), moderately active tectonic (Class 2), and low tectonics activity (Class 3 ). The results show that relative active tectonics indice value (lat) was obtained between 1.33 and 2.33 , indicating very high to moderately tectonic activity.

\section{Jeomorfik İndis kullanarak Gülbahçe Fay Zonu’ nun (GBFZ) Aktif Tektonik Değerlendirmesi, İzmir, Batı Anadolu, Türkiye}

\author{
Anahtar kelimeler \\ Gülbahçe fay zonu; \\ Jeomorfik indisler; \\ Morfometrik analiz; \\ Göreceli aktif tektonik \\ indisler; Coğrafi Bilgi \\ Sistemleri; Batı \\ Anadolu
}

Öz

Karadaki uzunluğu $24 \mathrm{~km}$ denizdeki uzunluğu $\sim 46 \mathrm{~km}$ olan ve sağ yanal ötelenmeli doğrultu atımlı fay karakterindeki Gülbahçe Fay Zonu, İzmir-Balıkesir Transfer Zonu' nun güney kısmında yer alan en önemli faylarından biridir. Gülbahçe Fay Zonu'nun aktif tektonik davranışını değerlendirmek için drenaj havzaları ve dağ önlerindeki jeomorfolojik indislerin morfometrik analizleri gerçekleştirilmiştir. ArcGIS ${ }^{\circledR} 10.5$ (ESRI) kullanılarak belirlenen 30 alt havzanın, dağ önü sinüslük indisi (Smf), vadi tabanı genişliği vadi yüksekliği oranı ( $V f)$, havza asimetri faktörü (Af), havza şekil indisi $(B s)$, drenaj yoğunluğu $(D d)$ ve hipsometrik integral $(\mathrm{Hi})$ değerleri belirlenmiş ve bu değerlerin ortalamaları alınarak her bir alt havzanın göreceli tektonik aktivitesi (lat) tanımlanmıştır. Smf değeri 1,05 ile 1,33, Vf değeri 0,21 ile 4,09, Af değerlerinin 25 ile 77; Bs değerlerinin 1,03 ile 3,06, Dd değerlerinin 0,84 ile 3,49 ve Hi değerlerinin 0,28 ile 0,67 aralığında olduğu belirlenmiştir. Tüm veriler, yüksek tektonik aktivite (Sınıf 1 ), orta derecede aktif tektonik (Sınıf 2) ve düşük tektonik aktivite (Sınıf 3) olmak üzere üç sınıfta ayrılarak incelenmiştir. Elde edilen sonuçlar, Gülbahçe Fay Zonu' nun göreceli aktif tektonik indis değerinin (lat) sırasıyla çok yüksek ile orta derecede tektonik aktiviteyi gösteren 1,33 ile 2,33 aralığında olduğunu gösterir.

C Afyon Kocatepe Üniversitesi

\footnotetext{
* This study is part of a Ph.D. thesis undertaken by the first author at the Institute of Natural and Applied Sciences, Dokuz Eylül University, Turkey.
} 


\section{Introduction}

Using geomorphic indices plays a crucial role to determine the relationship between erosion processes and tectonic activity of the region since the early 2000s (e.g., Silva et al. 2003, Bull 2007, Özkaymak and Sözbilir 2012, Özsayın 2016, Sağlam and Düzgün 2017, Saber et al. 2018). The effect of tectonic activity on drainage systems and landforms can be explained using geomorphological modelling and morphometric approaches. In regions where tectonism is active, the best-known geomorphic indicator in strike-slip faults is the horizontal offsets in rivers (e.g., Cowgill 2007, Cowgill et al. 2009, Fu and Awata 2007, Fu et al. 2005, Walker and Allen 2012). However, not only river offsets but also detailed studies about other geomorphic indices such as stream length gradient indice (SL), mountain-front sinuosity (Smf), valley floor width to height ratios (Vf), drainage density (Dd), and hypsometric integral (Hi) shed light on determining the tectonic activity of the regions with a vertical component of motion along the strike-slip faults (e.g., Owen et al. 1999, Keller and DeVecchio 2013, Khalifa et al. 2018). Therefore, to evaluate tectonic activity of GBFZ is used high-resolution satellite images (e.g., Burbank and Anderson 2001; Silva et al. 2003, Saber et al. 2018, Baize et al. 2015, Crupa et al. 2017, Walker and Allen 2012, Khalifa et al. 2018, Baharvand et al. 2020) and GIS-based software such as ArcGIS ${ }^{\circledR} 10.5$ (ESRI) (Faghih et al. 2016). GBFZ is located in the western part of the IBTZ (Kaya 1979, Sözbilir et.al 2003a, Emre et.al., 2005). This seismically active dextral strike-slip fault zone (Bozkurt and Sözbilir 2006) forms a boundary between Karaburun Peninsula and Urla block, faraway $45 \mathrm{~km}$ west of İzmir city from the east (Emre et al. 2005), extending for $\sim 24 \mathrm{~km}$ on land and $\sim 46 \mathrm{~km}$ under the sea (Emre et al. 2016, Ocakoğlu et al. 2005). With respect to GPS studies, the Karaburun Peninsula turn anti-clockwise due to dextral strikeslip nature of the N-S trending GBFZ (McClusky et al. 2000, Nyst and Thatcher 2004, Reilinger et al. 2006, Eyubagil et al. 2021). Although, GBFZ have been identified and documented as an active fault in active fault database of Turkey by Emre et al.
(2016); there is not detailed geomorphic studies about its tectonic activity. The scope of this research is to determine the GBFZ's relative tectonic activity by using geomorphic indices of sub-basins and mountain fronts in the study area. In addition, determining the vertical uplift rate in the northern margin of the Gülbahçe Basin by comparing $\mathrm{Vf}$ and Smf values and the geomorphic evolution active tectonics along the GBFZ by using the relative active tectonic indices are the aims of this study.

\section{Geological and Seismotectonic settings}

The study area is located in IBTZ, which delimit the Western Anatolia horst-graben system from the west (Sözbilir et al. 2003a, 2007, 2011, Özkaymak and Sözbilir 2008, Emre et al. 2016). The IBTZ acts as a transfer fault zone under an extensional tectonic regime with an annual GPS velocity of 20 mm/year (Aktuğ et al. 2009, 2016), and resulted in strike-slip-dominated zone of weakness (Kaya 1979, Ring et al. 1999, Sözbilir et al. 2003a, Erkül et al. 2005, Kaya et al. 2007, Sözbilir et al. 2007, Özkaymak and Sözbilir 2008, Uzel and Sözbilir 2008) which caused differential extension between western Anatolia and Aegean Sea region since at least Miocene (Ring et al. 1999, Sözbilir et al. 2009, 2011). This zone includes NE-SW trending dextral and NW-SE trending sinistral strike-slip faults, and E-W trending normal faults, which are the source of earthquakes that caused the surface rupture in the Holocene (Emre and Barka 2000, Sözbilir et al. 2005, 2007, Emre et al. 2016).

One of well-known fault zone at iBFZ is GBFZ, which acts as a dextral strike-slip fault (Emre and Barka 2000). Similar structures close to the study area, such as N-S trending strike-slip faults and approximately E-W trending smaller scale obliqueslip normal faults were also mapped by inci et al. (2003) and Sözbilir et al. (2009), respectively.

Gülbahçe Fault Zone and nearby area are one of the most seismically active region in western Anatolia according to the instrumental and historical earthquake cataloques. According to the prehistoric earthquake data, a total of 20 
earthquakes with an intensity greater than 6 occurred around the GBFZ. The most important of the prehistoric earthquakes in the region was the earthquake that occurred in 1389 AD with intensitiy X (Papazachos and Papazachou 1997; Taxeidis) (Figure 1). They reported that these earthquakes affected ancient buildings and recently built towns in Foça, Bergama andvcenter of Izmir. There are also many instrumental earthquakes that were affected along the GBFZ since 1901. Magnitudes of these earthquakes are ranging from 4 to 5.9. The most important earthquake is the 17 October 2005 and 20 October 2005 struck with a magnitude of 5.9 in Seferihisar with strike slip fault mechanism.

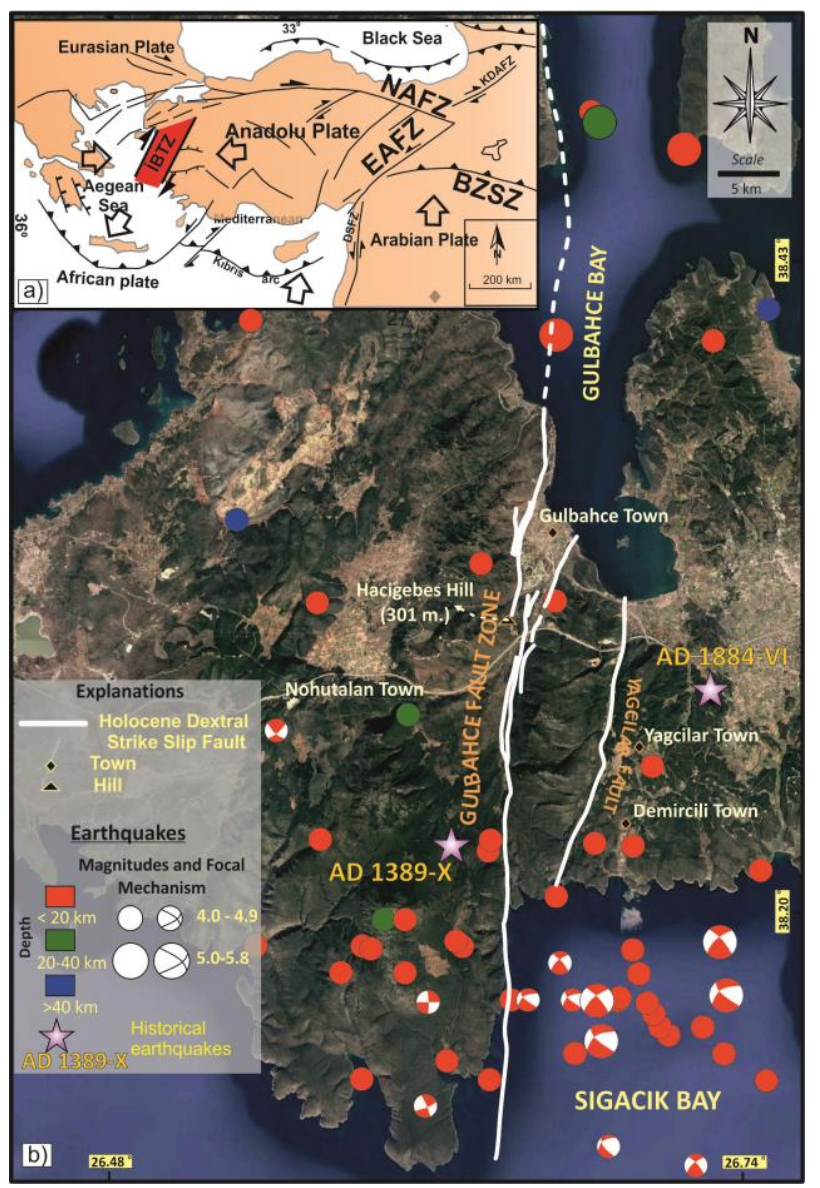

Figure 1. a) Tectonic framework map of the Anatolia White arrows represent the velocities of survey mode sites determined by Aktuğ et.al (2016) and Reilingier et al. (2006) b) Seismotectonic map of the GBFZ and its immediate surroundings region. White lines indicate an active fault according to Emre et al. (2016) (IBTZ: İzmir-Balıkesir Transfer Zone; NAFZ: North Anatolian Fault Zone; EAFZ: East Anatolian Fault Zone; BZSZ: Bitlis-Zagros Suture Zone).
This earthhquake affected especially, surrounding Demircili Bay to Yağcılar village having dextral slip sense. These arthquakes caused the callapse of houses and some buildings.

There are limited morphological studies to explain the Holocene activity of the GBFZ, while seismic studies in the seafloor proved that this zone cuts Holocene sediments (Ocakoğlu et al. 2005). According to the active faults database of Turkey, GBFZ is divided into three splays, which are named eastern, center, and western, and ranging from 21, 24, and $24 \mathrm{~km}$ long, respectively (Emre et al. 2016). While dextral offsets up to 1000 meters are observed on the main fault in the south, lateral displacements in the streams are much lower in the northern splay due to the oblique nature of the fault. The field studies indicated that GBFZ cut the rock units ranging from Triassic to Quaternary. These areas the Carnian - Rhaetian Güvercinlik Formation including limestone, dolomitic limestone, marl, sandstone, and Lias - Malm Nohutalan Formation, characterized by bioclastic limestone, Miocene Kocadağ volcanic rocks represented by rhyolitic lavas and pyroclastic, and Güvendik Formation which is composed of volcanic and non-volcanic lacustrine deposits.

These units are overlain by Quaternary deposits, representing by colluvial, fluvial sediments, alluvial fan deposits and fan-delta subaerial deposits (Figure 2).

\section{Methodology}

Geomorphic indices such as drainage basin asymmetry (Af), hypsometric integral $(\mathrm{Hi})$, the ratio of the valley-floor width to valley height ratio (Vf), basin shape (Bs), and mountain-front-sinuosity (Smf) are often used to evaluate active tectonism of the area (see Keller and Pinter 2002, Faghih et al. 2015 for detailed description of the indices). The Arc Hydro extension and ArcGIS ${ }^{\circledR} 10.1$ (ESRI) software are used to calculate morphometric parameters in this study. 


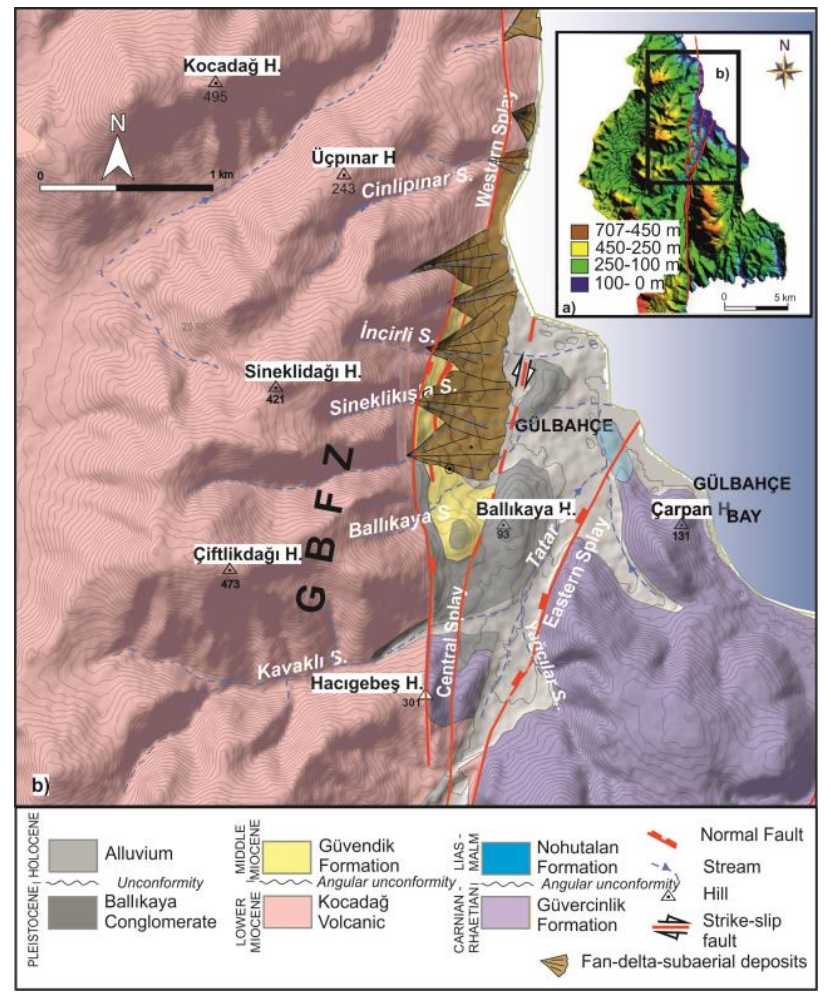

Figure 2. a)Digital elevation model images of GBFZ (Modified after Emre et al. 2016) b) Geology map of study area showing the lithological, structural, and morphological features of the Gülbahçe Fault Zone (GBFZ) which is divided into three splays (eastern, central, and western) towards to the Gülbahçe Bay.

Digital elevation data (DEMs) of the study area was obtained from Aster GDEM in 2009 (30 meters resolution). By using of these raster images were drawn rivers, and then were created sub-basins areas. The drainage network is classified according to Strahler (1964). As a result of the determination of 30 drainage basins (lower than 25.000 watershed accumulations were eliminated) affected by GBFZ related to strike-slip fault with normal fault component was investigated using geomorphic indices (Figure 3). The dotted line drainage basin area on the Tatar stream in Figure 3 is under the tectonic activity of the Kenelidağ Fault, which is a sinistral strike-slip fault (Göktaş 2014). Therefore, it is not included in the geomorphologic indice calculations.

\subsection{Mountain-front-sinuosity $\left(S_{m f}\right)$}

Mountain-front-sinuosity is used to describe the morphological evolution of the mountain front controlled by active tectonism. It is the ratio between the lengths of the mountain front along with the break of slope $\left(L_{m f}\right)$ and the length of a straight-line along with the same mountain front ( $L_{s}$ ) (Bull 1977a, Bull and McFadden 1977, Keller and Pinter 2002, Rockwell et al. 1984, Silva et al. 2003, Wells et al. 1988). It can be determined as,

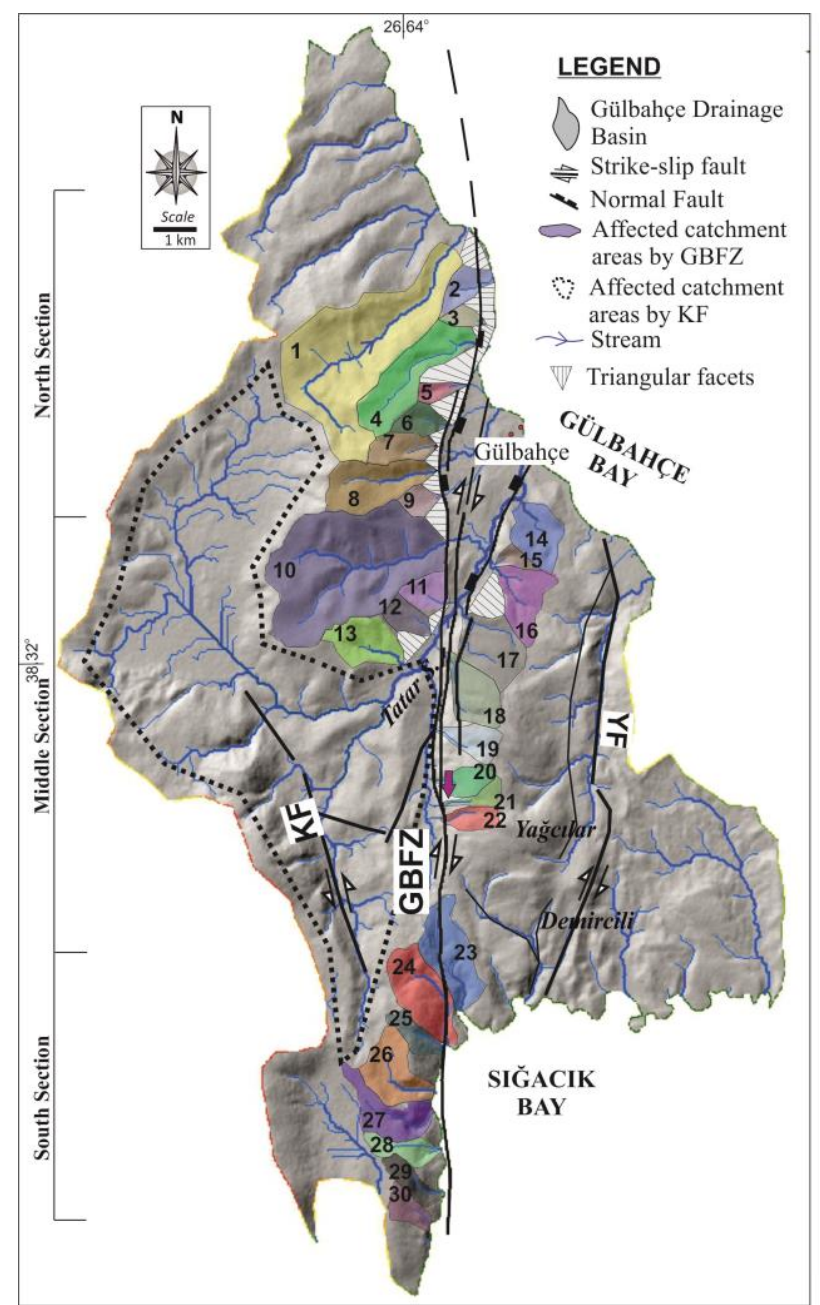

Figure 3. Studied catchments along the GBFZ (KF:Kenelidağ Fault; YF:Yağcılar Fault) (the dotted area illustrates the catchment areas under the tectonic activity of the Kenelidağ Fault).

$S m f=L m f / L s$

where $\mathrm{Smf}$ is mountain-front-sinuosity, $\mathrm{Lmf}$ is the length of mountain front, and $L s$ is the length of a straight line along the same mountain (Keller and Pinter 1996). According to Bull (2007), values of Smf are divided into three classes: class 1 represents Smf values less than $<1.4$ (very high active), class 2 represents Smf values between 1.4 and 3.0 (semi-active or moderately active), and 
class 3 represents Smf values higher than > 3.0 (inactive).

\subsection{Valley floor width to valley height ratio (Vf)}

The ratio of valley floor width to valley height (Vf) is an essential indicator for determining the tectonic evaluation of rivers (Keller and Pinter 2002). Obtaining the $\mathrm{Vf}$ value at high or low values depends on the shape of the valley. It is defined as,

$$
V f=2 V f w /[(E l d-E s c)+(E r d-E s c)]
$$

where Vfw is the width of the valley floor, Esc is the average elevation of the valley floor, and Eld and Erd are the respective elevations of the left and right valley divide looking downstream. Vf was classified into three classes. Classes:3 ( $\mathrm{Vf}$ values $\geq 1.0)$, Classes: $2(0.5 \leq \mathrm{Vf} \leq 1.0)$, and Classes: $1(\mathrm{Vf} \leq 0.1)$ represent low, moderate, and high tectonic activity, respectively (El Hamdouni et al. 2007).

\subsection{Drainage Density (Dd)}

The drainage density (Dd), which gives general information about the climatic characteristics and geology of the study area (Horton 1932, Rana et al. 2016, Tarboton et al. 1991, Utlu and Özdemir 2018), is obtained by the ratio of the length of the stream $(\mathrm{L})$ to the area of the basin $(\mathrm{A})$ (Gregory and De Walling 1973). To calculate drainage density used formula is,

$$
\operatorname{Dd}\left(\mathrm{km} / \mathrm{km}^{2}\right)=L / A
$$

where $L$ is stream length and $A$ is the total area of the basin. Higher density indicates less tectonic activity. (Keller and Pinter 2002, Khalifa et al. 2018). In addition, lower Dd values can be obtained in rock masses with high strength (due to the seepage effect) (Patton 1988, Uzun 2019). Dd values are classified into three classes where Classes:1 (Dd $\leq 2)$, Classes: 2 ( $2<\mathrm{Dd} \leq 3)$, Classes: 3 $(\mathrm{Dd}>3$ ) indicates high, moderate and low tectonic activity, respectively (Nugroho et.al., 2020).

\subsection{Basin shape indice (Bs)}

The geometry of drainage basins can be determined from basin shape indices (Bs) (Cannon 1976, Bull and McFadden 1977, Ramírez-Herrera 1998, El Hamdouni et al. 2007, Omidali et al. 2015, Saber et al. 2018). Bs indice can be defined by the following formula;

$$
B s=B l / B w
$$

where $\mathrm{Bl}$ is the length of the drainage basin, and $B w$ is the length of the widest part of the basin. High Bs values indicate the drainage basin's longitudinal geometry, indicating high tectonic activity (Ramírez-Herrera 1998, Softa et al. 2018, Saber et al. 2018). This value is divided into three classes to define the degree of activity of tectonics: Class: 1 , high ( $\mathrm{Bs} \geq 4$ ); Class: 2 , moderately ( $3 \leq \mathrm{Bs}$ $<4)$; Class:3, low (Bs $\leq 3$ ) (El Hamdouni et al. 2007).

\subsection{Hypsometric Integral (Hi)}

The hypsometric curve used in determining the geomorphological development stages of a region (Strahler 1952b) shows the altitude distribution of that region (Pike and Wilson 1971). This curve is obtained by projecting the relative height onto the relative field. The hypsometric integral $(\mathrm{Hi})$ is determined by calculating the area under the hypsometric curve, and the formula used is presented below:

$$
H i=(h-h \min ) /(h \max -h \min )
$$

where, $\mathrm{h}$ is the mean elevation; $\mathrm{hmin}$ and $\mathrm{hmax}$ are the minimum and maximum elevation, respectively. In general, if the $\mathrm{Hi} \geq 0.5$ (Class 1 ) values, it means the catchment area is relatively less eroded and tectonically active, whereas the $\mathrm{Hi}$ $\leq 0.4$ (Class 3 ) values indicate catchment area is old and tectonically quiescent (EI Hamdouni et.al 2007, Dehbozorgi et.al., 2010, Mahmood and Gloaguen 2012, Selim et.al., 2013). Intermediate values between $0.4<\mathrm{Hi}<0.5$ are characteristic of Class 2, which indicates moderately tectonic activities. 


\subsection{Basin Asymmetry Factor (Af)}

The basin asymmetry factor $(A f)$ is a geomorphological indices used to determine tectonic tilting at the scale of a drainage basin (Hare and Gardner 1985, Keller and Pinter 2002). Af is defined as:

$$
A f=100\left(\frac{A r}{A t}\right)
$$

where $\mathrm{Ar}$ is the right side of the master drainage area (looking downstream) and At is the total area of the basin. Af values were examined in 3 classes as $43 \leq \mathrm{Af}<57$ (Class 3 ), $35 \leq \mathrm{Af}<43$ or $57 \leq \mathrm{Af}<63$ (Class 2), and $A f \geq 63$ or $A f<35$ (Class 1 ). Af is close to 55 if there is little tilting where the tectonic activity is high (El Hamdouni et.al 2007).

\subsection{Relative Tectonic Activity (lat)}

To evaluate the distribution of relative tectonic activity along GBFZ was used an average of six calculated geomorphic indices (lat) (El Hamdouni et.al 2007). lat is calculated as:

$$
\text { Iat }=S / N
$$

Where $\mathrm{S}$ is the defined class values of geomorphic indices and $\mathrm{N}$ is a number of used geomorphic indices. lat was classified into four classes: 1 ( $1<$ lat $\leq 1.5) ; 2(1.5<$ lat $\leq 2.0) ; 3(2.0<$ lat $\leq 2.5)$ and 4 (lat $>2.5$ ) (El Hamdouni et.al 2007), which indicate very high, high, moderately and low, degree of active tectonics, respectively.

\section{Results}

Before interpreting the geomorphological indice results, the abrasion resistance of the rocks in the study area was determined. For this purpose, the rock strengths of the lithological units were determined according to the Geological Strength Index (GSI) from Marinos and Hoek (2000). Using a GSI chart, the rocks in the study area described according to their lithology, structure, and surface conditions of the discontinuities (Table 1). The indice of Smf was calculated along the mountain front shaped by the normal slip component of the northern section (Figure 4). The aerial lengths (Lmf) and the overall lengths (Ls) of the defined mountain fronts and classified Smf indices are presented in Table 2.

Table 1. GSI (Geological Strength Index) classification up to Hoek and Marinos (2000) for rock masses on the study area

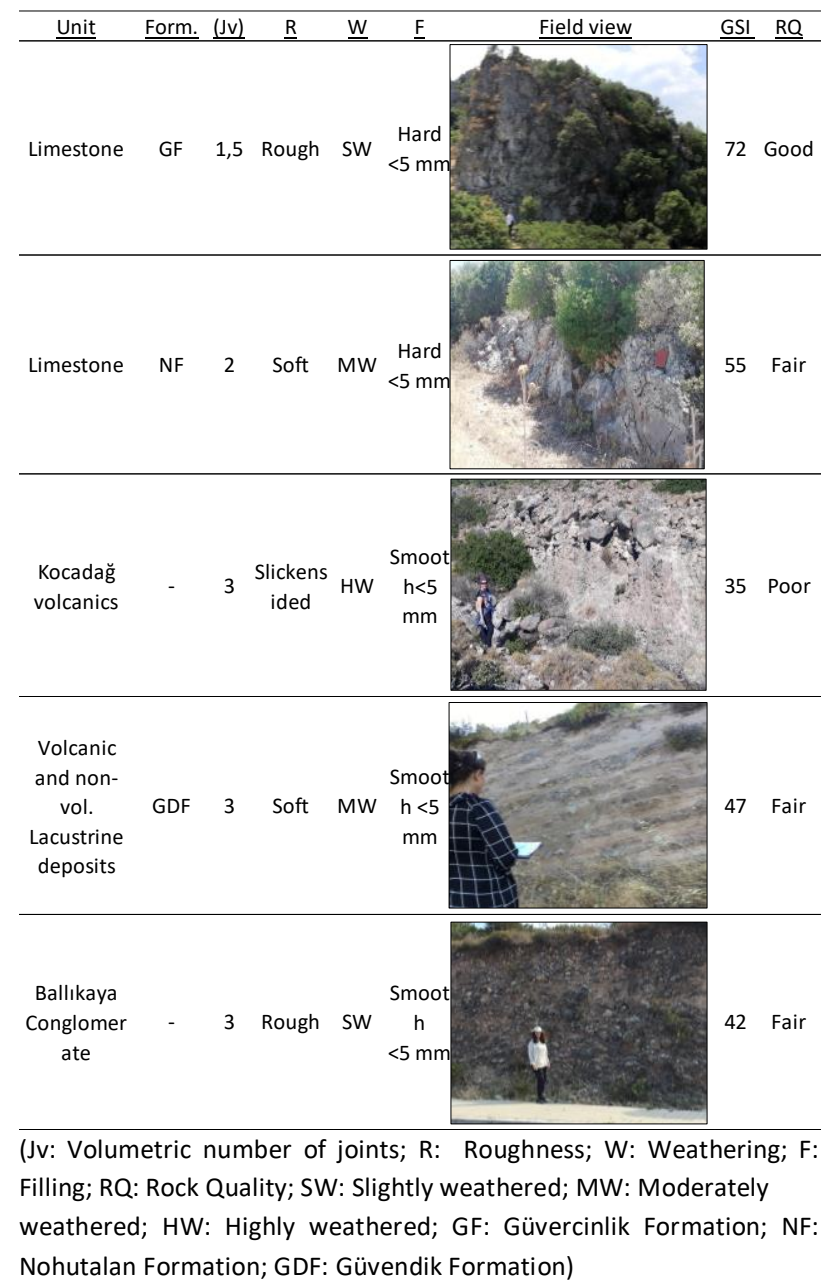

According to the obtained GSI results, the strength of the rocks defined at the study area is generally fair or higher. It shows that the tectonic uplift is more dominant in the drainage areas developed on these rocks with high strength against weathering. $\mathrm{Vf}$ values were calculated in 17 drainage areas located on GBFZ's uplift blocks (Figure 5). It was determined that the calculated $\mathrm{V}$ values varied between 0.91 and 2.85 which indicate " $V$ " shaped valleys and " $U$ " shaped valleys, respectively. The Af values for the 30 catchments along GBFZ were 
determined for the western, central, and southern of the study area (Figure 5). The obtained values by divided into three classes presented in Table 2. Af values for $2,4,8,10,13,18,19,21,22$, and 24 subbasins are significantly greater than 63 or smaller than 35. The minimum Af values belong to 1, 9, 14, 15 , and 20 sub-basins, located generally at the northern section of the study area. Drainage density (Dd) was determined for 30 catchments in the study area (Table 2). Dd values range from 0.84 (Class 1) to 3.49 (Class 3). Catchments 3, 5, and 21 have less tectonic uplift than the other catchment areas where they have Dd value of more than 3.0 $\mathrm{km} / \mathrm{km}^{2}$ (Class 3).

The Bs indice was calculated for 30 sub-basin areas (Table 2). Evaluating basin shape indice (Bs) along the GBFZ shows that Bs values range from 1.03 (Class 3 ) to 3.25 (Class 1 ). Hi-indice were calculated for each sub-basins and the results of the $\mathrm{Hi}$-indice were categorized by dividing the study area as northern, central, and southern. According to the calculated $\mathrm{Hi}$ values for each sub-basin at the study area, the values of $\mathrm{Hi}$ range from 0.28 to 0.67 which were classified Class $3(\mathrm{Hi}<0.4)$ and Class 1 ( $\mathrm{Hi} \geq 0.5$ ), respectively (Table 2 and Figure 6 ). The figure shows the hypsometric curves recorded concave curves for catchments $1,4,5,6,7,8,11$, $12,13,14,15,19,20,21,22$, and 25; concaveconvex curves in catchments $2,3,16,17,18,23$, and 29; convex curves in catchments $9,24,26,27,28$, and 30 .

All the determined morphologic indices are presented in Table 2 which all the values are classified into three classes show high (Class 1)moderate (Class 2), and low (Class 3) tectonic activity.
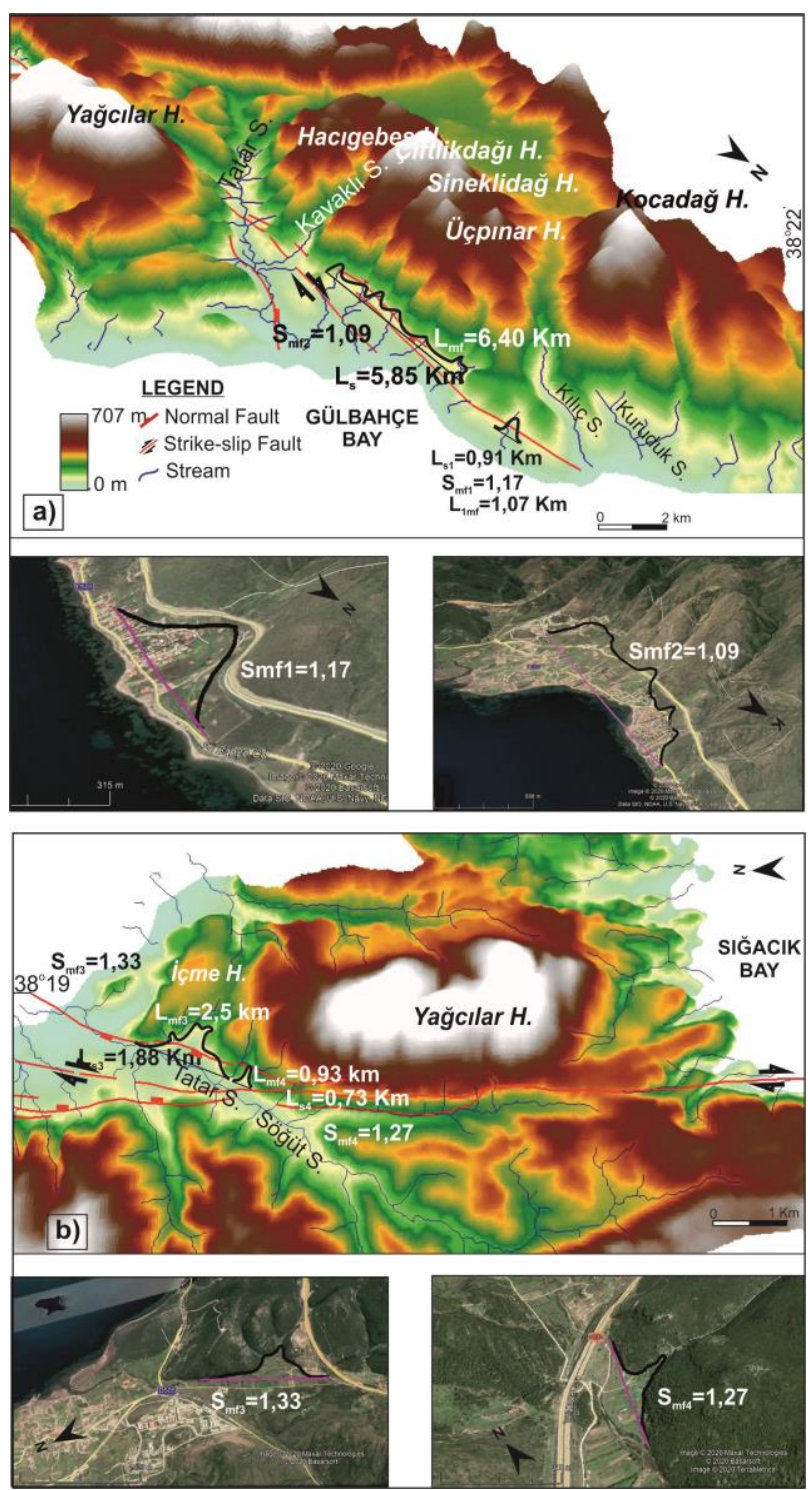

Figure 4. Areas which are calculated of mountain-frontsinuosity (Smf) a) Smf values on the western splay b) Smf values on the eastern splay (Lmf: the lengths of the mountain front along with the break of a slope; Ls: the length of a straight-line along with the same mountain front). 


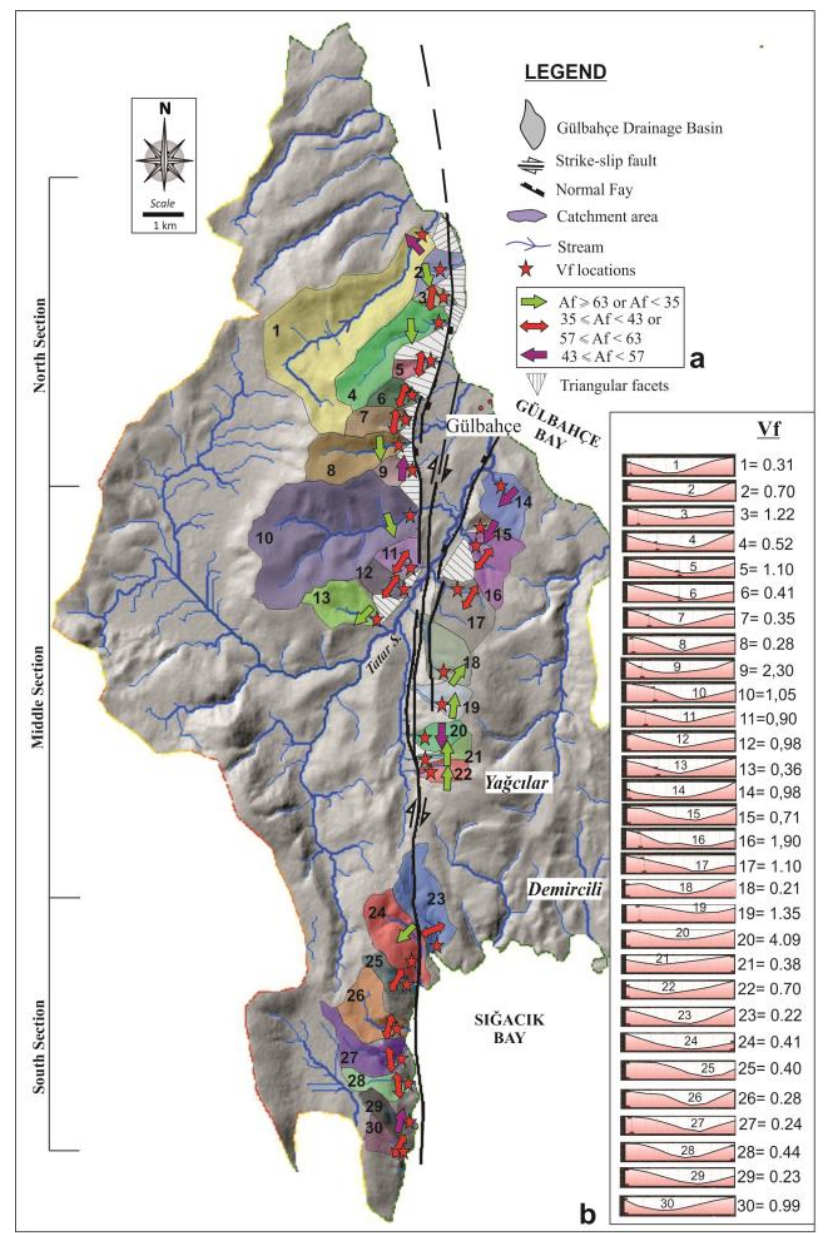

Figure 5. a) Basin asymmetry factor map of the study area (Green, red, and purple arrows show subbasin areas which are under high, moderate, and low tectonics activity or strong lithological control, respectively) b) $\mathrm{Vf}$ values calculated in 30 drainage basins in the study area and affected by GBFZ (Vf: Valley floor width to valley height ratio)(KF: Kenelidağ Fault; YF: Yağcılar Fault).

\section{Discussion and Conclusion}

In the literature, the ratio between $\operatorname{Smf}$ and $V f$ is used to determine the tectonic activity of faults (e.g., Rockwell et al. 1984, Silva et al. 2003, Yıldırım 2014, Softa et al. 2018, Saber et al. 2018, Özsayın, 2016). Smf values were calculated for the sub-basin areas where are located nearby normal fault splays of GBFZ. The average of the $\mathrm{Vf}$ values of these areas relevant with $\mathrm{Smf}$ values was calculated. All Smf values $(\mathrm{Smf}<1.4)$ indicate that all splays of GBFZ are young and active tectonic uplift.

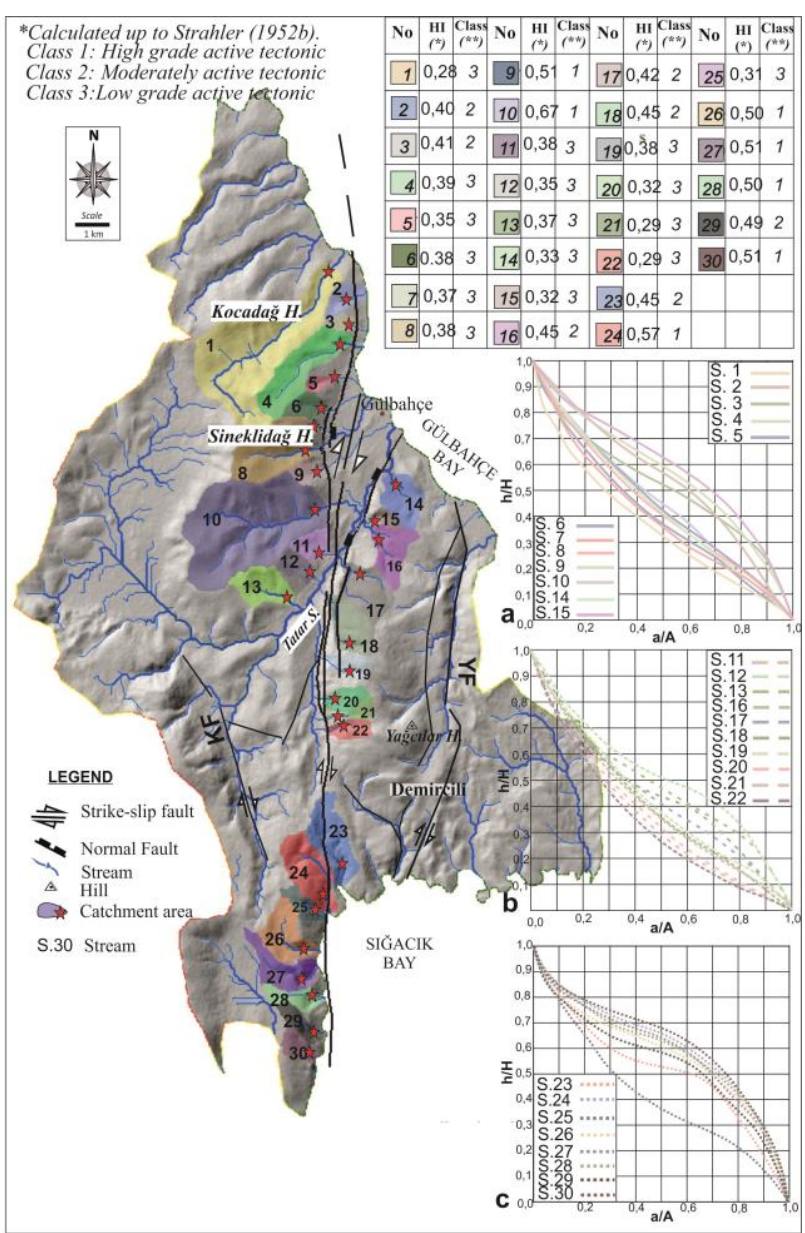

Figure 6. Hypsometric integral (HI) Classes and hypsometry curves of 30 catchments along the GBFZ a, b, c) the curves represent northern, central, and southern sections of GBFZ, respectively $(\mathrm{h} / \mathrm{H}$ : relative altitude; $\mathrm{a} / \mathrm{A}$ : relative area) (KF: Kenelidağ Fault; YF: Yağcılar Fault).

Vf values where are calculated Smf values show high vertical uplift rates along the north of the Gülbahçe Basin, except catchments 3, 5, 9, and 10. Especially, Vf values obtained from drainage basins affected western splay of GBFZ were calculated less than 0.5 (Class 1 ) that is related " $V$ " shaped valleys indicated high tectonic activity. Higher Vf values ( $\geq$ 1.0), dominant along the eastern splay of GBFZ show erosion processes and less tectonic activity (Class 3). The obtained Vf values and Smf values were plotted on the chart suggested by Rockwell et al. (1984) (Figure 7). According to plotting the average of the Vf and Smf values, the vertical uplift rate for the northern section of Gülbahçe Basin is obtained on Class 1, which is associated with uplift rates larger than $>0.5 \mathrm{mmy}^{-1}$ (Rockwell et al. 1984). This vertical uplift rate (between 0.60 and 0.80 
$\mathrm{mmy}^{-1}$ ) is also a uniform slip rate for IBTZ, which ranges from 0.2 to $8.0 \mathrm{mmy}^{-1}$ (e.g., Özkaymak 2014, Aktuğ et.al 2009) which were obtained by using of GPS measurements. Smf vs. Vf values indicate high correlation with $\mathrm{R}^{2}=0.89$.

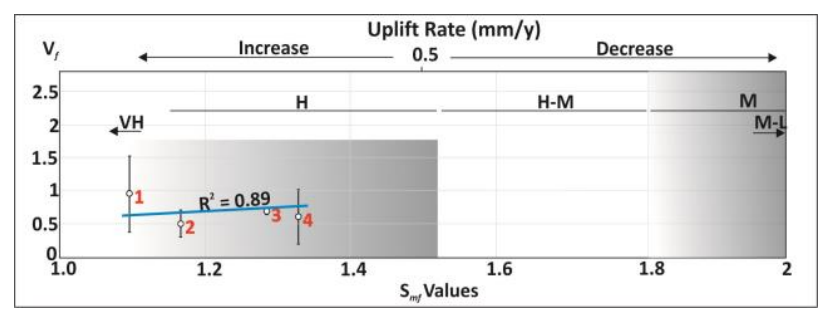

Figure 7. Plot of mountain-front-sinuosity (Smf) versus valley floor width-to-valley height ratio (Vf). Vertical bars indicate the standard deviation for $\mathrm{Vf}$ values. Uplift rate $\left(\mathrm{mmy}^{-1}\right)$ values from Rockwell et al. 1984 (VH: Very high, H: High, $\mathrm{H}-\mathrm{M}$ : High to moderate, M:Moderate, $\mathrm{ML}$ : Moderate to Low, L: Low, Red numbers indicate the mountain-front)

$D d$ values give general information about geology, climate conditions, and tectonics activity (Horton, 1932; Rana et al. 2016, Tarboton et al. 1991, Utlu and Özdemir 2018). In general, high Dd values indicate weathering and maturity degree of drainage basins. In addition, low Dd values are pointed out as high rock quality strength due to the seepage effect (Patton 1988, Uzun 2019) (e.g., catchments classified in $1^{\text {st }}$ class in Table 2 ). Especially, Dd values of catchments located central section of GBFZ and consist of limestone with good rock quality that belongs to Güvercinlik Formation have the lowest $\mathrm{Dd}$ value. This $\mathrm{Dd}$ value characterizes nearly straight channels with a recent movement activity.

Investigating the sub-basins hypsometric curve and $\mathrm{Hi}$ values indicate that $\mathrm{Hi}<0.4$ (Class 3) were commonly dominant along the western and central sections of GBFZ. Hence, the tectonic activity could be assumed inactive (Pike and Wilson 1971). On the other hand, Hi values could be affected directly by the rock strength (El Hamdouni et al. 2008, Khalifa et al. 2018). The catchments along the southern section of GBFZ (no. 24, 26, 27, 28 and 30) are young (Class 1) compare to the other sections. By determining the ratio between $\mathrm{BI}$ (length of the drainage basin) and Bw (length of the widest part of the basin) (Table 2) the Bs indice was calculated and classified into three classes from highest (class 1 ) to lowest (class 3 ) tectonic activity. The obtained Bs values indicate that basins are concern generally moderately active and inactive tectonic. According to the calculations, Af values are very interesting. The northern part of the GBFZ (western block) slopes to the south, the middle part (eastern block) to the north. The south block is seen in equilibrium. The reason for the slope of the area between Yağcılar fault and GBFZ towards north can be explained by the fact that the GBFZ divides into three splays in the north and creates a depression basin bordered by normal faults. While the northern part of the Gülbahçe fault collapses, the north of the Karaburun peninsula rises (the western block dips to the south). This uplift and subsidence occur parallel to the fault. Because of this situation and annual uplift rate of basin, it may indicate that the Karaburun peninsula may break away from Anatolia in the future and then turn into an island like Chios, located in the west. Splaying of the fault in the north and related subsidence around Gülbahçe bay can be explained by the counter anti-clockwise rotational movement of the Karaburun peninsula block which was also stated by geodetic and paleomagnetic studies (Aktuğ and Kılıçoğlu 2006, Uzel et al. 2013, Eyubagil et al. 2021). Besides this, obtained results show that the western splay of GBFZ is more affected on the drainage basins with a high relative tectonic activity. On the other hand, the eastern splay of GBFZ affected the drainage basins less with a 


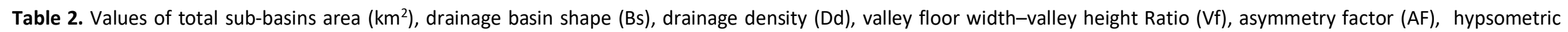
integral ( $\mathrm{Hi})$, mountain front sinuosity (Smf), and relative tectonic activity (lat) of the different catchments of the study area. All results related to the tectonic activity classification obtained were compared with the lithology where the drainage area developed (KF:Kocadağ Formation; BC: Ballıkaya Conglomerate; GF:Güvercinlik Formation; P: Poor; F:Fair; G: Good)(for all classes 1:High tectonics activity; 2:Moderately activity; 3: Low tectonics activity; on- 1: Standard deviation; Vfm: Vfmean )

\begin{tabular}{|c|c|c|c|c|c|c|c|c|c|c|c|c|c|c|c|c|c|c|c|c|c|c|c|c|}
\hline No & $\begin{array}{l}\text { Area } \\
\left(\mathrm{km}^{2}\right)\end{array}$ & $\begin{array}{c}\mathrm{BI} \\
(\mathrm{km})\end{array}$ & $\begin{array}{l}\text { Bw } \\
(\mathrm{km})\end{array}$ & Bs & $\begin{array}{l}\text { Class } \\
\text { (Bs) }\end{array}$ & $\begin{array}{c}\mathrm{L} \\
(\mathrm{km})\end{array}$ & $\begin{array}{c}\mathrm{Dd} \\
\left(\mathrm{km} / \mathrm{km}^{2}\right)\end{array}$ & $\begin{array}{l}\text { Class } \\
\text { (Dd) }\end{array}$ & Vf & $\mathrm{Vf}_{\mathrm{m}}$ & on- 1 & $\begin{array}{c}\text { Class } \\
\text { (Vf) }\end{array}$ & $\mathrm{Ar}$ & $\begin{array}{l}\text { Af } \\
(\%)\end{array}$ & $\begin{array}{l}\text { Class } \\
\text { (Af) }\end{array}$ & HI & $\begin{array}{c}\text { Class } \\
\text { (Hi) }\end{array}$ & Smf & $\begin{array}{l}\text { Class } \\
\text { (Smf) }\end{array}$ & lat & $\begin{array}{l}\text { Tectonic } \\
\text { Activity }\end{array}$ & Lithology & GSI & $\begin{array}{c}\text { Rock } \\
\text { Quality }\end{array}$ \\
\hline 1 & 10.26 & 4.67 & 2.74 & 1.70 & 3 & 11.50 & 1.12 & 1 & 0.31 & \multirow{2}{*}{0.51} & \multirow{2}{*}{0.28} & 1 & 5.33 & 52 & 3 & 0.28 & 3 & \multirow{2}{*}{1.17} & \multirow{2}{*}{1} & 2.00 & High & $\mathrm{KF}$ & 35 & $P$ \\
\hline 2 & 0.86 & 2.68 & 1.30 & 2.06 & 2 & 2.45 & 2.85 & 2 & 0.70 & & & 2 & 0.26 & 30 & 1 & 0.40 & 2 & & & 1.66 & High & $\mathrm{KF}$ & 35 & $P$ \\
\hline 3 & 0.39 & 2.83 & 1.05 & 2.69 & 2 & 1.50 & 3.85 & 3 & 1.22 & \multirow{5}{*}{0.9} & \multirow{5}{*}{0.68} & 3 & 0.14 & 36 & 2 & 0.41 & 2 & \multirow{5}{*}{1.09} & \multirow{5}{*}{1} & 2.17 & Moderate & $\mathrm{KF}$ & 35 & $P$ \\
\hline 4 & 3.36 & 2.68 & 1.17 & 2.29 & 2 & 4.50 & 1.34 & 1 & 0.52 & & & 2 & 1.13 & 34 & 1 & 0.39 & 3 & & & 1.17 & Very high & $\mathrm{KF}$ & 35 & $P$ \\
\hline 5 & 0.40 & 5.08 & 2.52 & 2.01 & 2 & 1.25 & 3.13 & 3 & 1.10 & & & 3 & 0.24 & 60 & 2 & 0.35 & 3 & & & 2.33 & Moderate & $\mathrm{KF}$ & 35 & $P$ \\
\hline 6 & 0.76 & 3.52 & 1.08 & 3.25 & 1 & 1.36 & 1.79 & 1 & 0.41 & & & 1 & 0.28 & 37 & 2 & 0.38 & 3 & & & 1.50 & High & $\mathrm{KF}$ & 35 & $P$ \\
\hline 7 & 1.07 & 1.26 & 1.11 & 1.13 & 3 & 2.18 & 2.04 & 2 & 0.35 & & & 1 & 0.39 & 36 & 2 & 0.38 & 3 & & & 2.00 & High & $\mathrm{KF}+\mathrm{BC}$ & $35 / 42$ & $\mathrm{P} / \mathrm{F}$ \\
\hline 8 & 1.76 & 1.73 & 0.90 & 1.92 & 3 & 3.14 & 1.20 & 1 & 0.28 & \multirow{7}{*}{0.67} & \multirow{7}{*}{0.44} & 1 & 1.36 & 77 & 1 & 0.51 & 1 & & & 1.33 & High & $\mathrm{KF}+\mathrm{BC}$ & $35 / 42$ & $\mathrm{P} / \mathrm{F}$ \\
\hline 9 & 0.53 & 1.81 & 0.66 & 2.74 & 2 & 0.92 & 1.74 & 1 & 2.30 & & & 3 & 0.28 & 53 & 3 & 0.67 & 1 & & & 2.20 & Moderate & $\mathrm{KF}+\mathrm{BC}$ & $35 / 42$ & $\mathrm{P} / \mathrm{F}$ \\
\hline 10 & 10.91 & 2.09 & 1.57 & 1.33 & 3 & 9.20 & 0.84 & 1 & 1.05 & & & 3 & 3.58 & 33 & 1 & 0.33 & 3 & & & 2.00 & High & $\mathrm{KF}+\mathrm{BC}$ & $35 / 42$ & $\mathrm{P} / \mathrm{F}$ \\
\hline 11 & 0.91 & 2.76 & 0.90 & 3.06 & 1 & 1.31 & 1.44 & 1 & 0.90 & & & 2 & 0.38 & 42 & 2 & 0.38 & 3 & & & 1.80 & High & $\mathrm{KF}$ & 35 & $P$ \\
\hline 12 & 0.78 & 1.97 & 0.70 & 2.81 & 2 & 0.90 & 1.15 & 1 & 0.98 & & & 2 & 0.28 & 36 & 2 & 0.35 & 3 & & & 2.00 & High & $\mathrm{KF}$ & 35 & $P$ \\
\hline 13 & 1.83 & 1.84 & 0.65 & 2.83 & 2 & 2.31 & 1.26 & 1 & 0.36 & & & 1 & 0.52 & 28 & 1 & 0.37 & 3 & \multirow{2}{*}{1.33} & \multirow{2}{*}{1} & 1.50 & Very high & $\mathrm{KF}$ & 35 & $\mathrm{P}$ \\
\hline 14 & 1.63 & 1.43 & 0.83 & 1.72 & 3 & 1.86 & 1.14 & 1 & 0.98 & & & 2 & 0.74 & 45 & 3 & 0.33 & 3 & & & 2.33 & Moderate & NF & 55 & $\mathrm{~F}$ \\
\hline 15 & 0.37 & 1.55 & 0.97 & 1.59 & 3 & 0.97 & 2.62 & 2 & 0.71 & 0.71 & 0 & 2 & 0.2 & 54 & 3 & 0.32 & 3 & 1.27 & 1 & 2.33 & Moderate & GF & 72 & G \\
\hline 16 & 1.75 & 1.05 & 0.72 & 1.45 & 3 & 2.70 & 1.43 & 1 & 1.90 & & & 3 & 1.08 & 62 & 2 & 0.45 & 2 & & & 2.20 & Moderate & GF & 72 & G \\
\hline 17 & 2.23 & 1.16 & 0.43 & 2.69 & 2 & 3.10 & 1.54 & 1 & 1.10 & & & 3 & 1.43 & 64 & 2 & 0.42 & 2 & & & 2.00 & Moderate & GF & 72 & G \\
\hline 18 & 1.70 & 1.94 & 0.75 & 2.58 & 2 & 2.60 & 1.39 & 1 & 0.21 & & & 1 & 1.26 & 74 & 1 & 0.45 & 2 & & & 1.40 & High & GF & 72 & G \\
\hline 19 & 0.98 & 1.34 & 1.01 & 1.32 & 3 & 1.23 & 1.53 & 1 & 1.35 & & & 3 & 0.69 & 70 & 1 & 0.38 & 3 & & & 2.20 & Moderate & GF & 72 & G \\
\hline 20 & 0.84 & 2.55 & 1.55 & 1.64 & 3 & 1.25 & 1.26 & 1 & 4.09 & & & 3 & 0.41 & 49 & 3 & 0.32 & 3 & & & 2.60 & Moderate & GF & 72 & G \\
\hline 21 & 0.49 & 2.18 & 1.37 & 1.59 & 3 & 1.71 & 1.49 & 1 & 0.38 & & & 1 & 0.31 & 63 & 1 & 0.29 & 3 & & & 1.80 & High & GF & 72 & G \\
\hline 22 & 0.75 & 1.50 & 0.67 & 2.23 & 2 & 1.18 & 3.49 & 3 & 0.70 & & & 2 & 0.22 & 29 & 1 & 0.29 & 3 & & & 2.20 & Moderate & GF & 72 & G \\
\hline 23 & 2.42 & 0.89 & 0.86 & 1.03 & 3 & 2.10 & 1.57 & 1 & 0.22 & & & 1 & 0.94 & 39 & 2 & 0.45 & 2 & & & 1.80 & High & GF & 72 & G \\
\hline 24 & 2.49 & 2.08 & 0.79 & 2.63 & 2 & 2.80 & 0.87 & 1 & 0.41 & & & 1 & 0.63 & 25 & 1 & 0.57 & 1 & & & 1.20 & High & GF & 72 & G \\
\hline 25 & 0.80 & 1.96 & 0.77 & 2.54 & 2 & 1.39 & 1.12 & 1 & 0.40 & & & 1 & 0.51 & 64 & 2 & 0.31 & 3 & & & 1.80 & High & GF & 72 & G \\
\hline 26 & 2.07 & 1.93 & 0.73 & 2.64 & 2 & 2.30 & 1.74 & 1 & 0.28 & & & 1 & 1.27 & 61 & 2 & 0.50 & 1 & & & 1.40 & High & GF & 72 & G \\
\hline 27 & 1.99 & 1.78 & 0.64 & 2.78 & 2 & 3.10 & 1.11 & 1 & 0.24 & & & 1 & 1.21 & 61 & 2 & 0.51 & 1 & & & 1.40 & High & GF & 72 & G \\
\hline 28 & 0.95 & 1.81 & 1.28 & 1.41 & 3 & 1.90 & 1.56 & 1 & 0.44 & & & 1 & 0.6 & 63 & 2 & 0.50 & 1 & & & 1.60 & High & GF & 72 & G \\
\hline 29 & 0.81 & 1.71 & 1.65 & 1.03 & 2 & 1.40 & 2.00 & 2 & 0.23 & & & 1 & 0.41 & 51 & 3 & 0.49 & 2 & & & 2.00 & High & GF & 72 & G \\
\hline 30 & 0.74 & 2.04 & 1.57 & 1.29 & 2 & 0.78 & 1.73 & 1 & 0.99 & & & 2 & 0.46 & 62 & 2 & 0.51 & 1 & & & 1.60 & High & GF & 72 & G \\
\hline
\end{tabular}


moderate relative tectonic activity. These results are also compatible with AF data, since the eastern

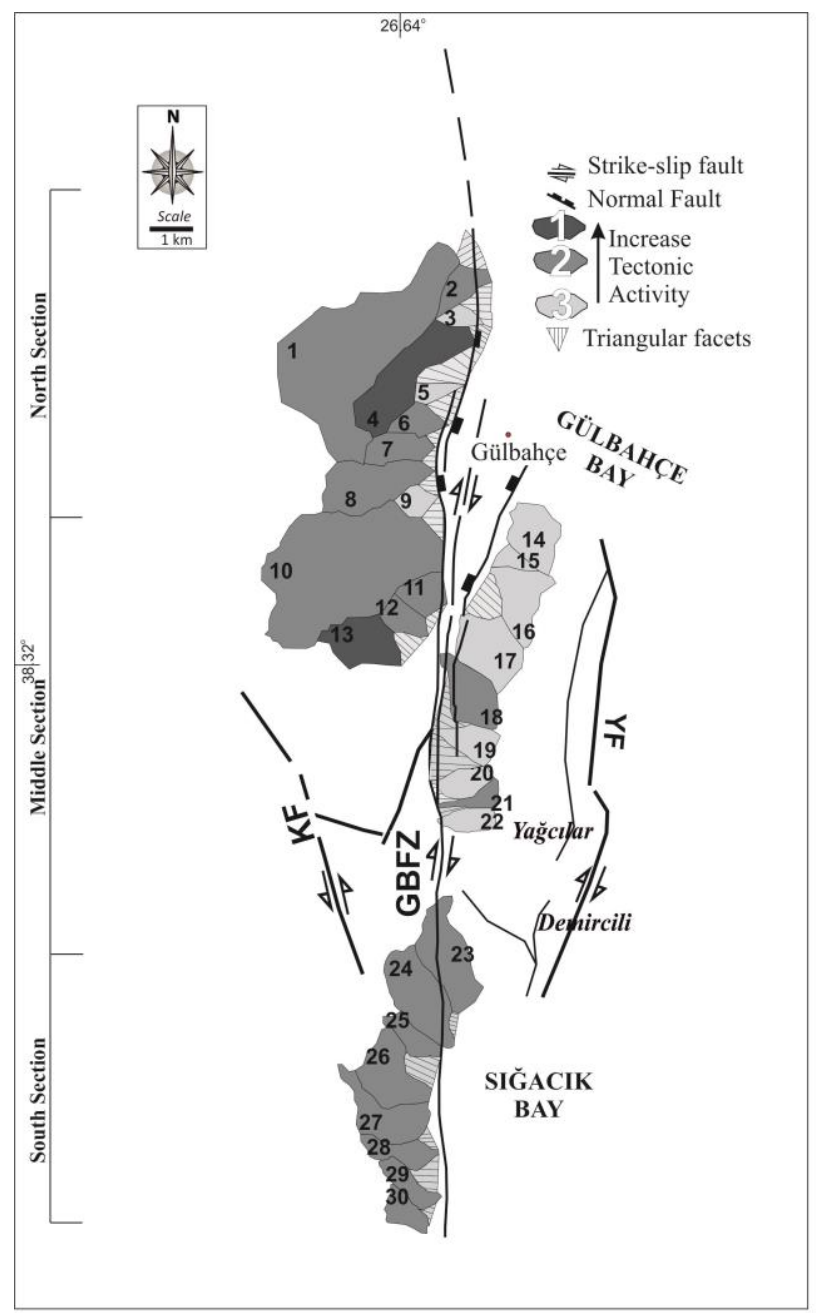

Figure 8. Relative tectonic activity classification (lat) map (Class 1: Very high tectonic activity; Class 2: High tectonic activity; Class 3: Moderate tectonic activity)

edge of the rising Karaburun peninsula is controlled by the western splay of the GBFZ.

Consequently, by calculating the mean of all geomorphic indices, it was determined that $\boldsymbol{I}_{\boldsymbol{a t}}$ value was between 1.33 and 2.33. This indicates that tectonic activity is high and moderate in the region (Figure 8).

This study illustrates that geomorphologic indices, including Smf, $\mathrm{Vf}, \mathrm{Dd}, \mathrm{Bs}, \mathrm{Hi}$, and $\mathrm{Af}$, relevant tectonics activity along GBFZ which is a dextral strike-slip fault with vertical components at the northern splays of GBFZ. All the obtained values of geomorphic indices are firstly classified and secondly correlated with relevant tectonics activity. According to Smf versus Vf values, the western block of the northern part of the Gülbahçe Basin is young and active tectonic uplift. The comparison of vertical uplift rates obtained according to the geomorphological indice studies of different faults is presented in Table 3.

Table 3. Vertical uplift rates determined up to morphological analysis in different types of strike-slip faults in Turkey

\begin{tabular}{|c|c|c|c|}
\hline Name of the fault & Fault Type & $\begin{array}{c}\text { Vertical } \\
\text { Uplift rate of } \\
\text { basin } \\
\mathrm{mm} / \text { year }\end{array}$ & Reference \\
\hline $\begin{array}{c}\text { Ovacık Fault } \\
\text { (Eastern Turkey) }\end{array}$ & $\begin{array}{l}\text { Sinistral strike- } \\
\text { slip fault }\end{array}$ & $\geq 0.5$ & $\begin{array}{l}\text { Yazıcı et } \\
\text { al.,, } 2018\end{array}$ \\
\hline $\begin{array}{l}\text { East Anatolian } \\
\text { Fault }\end{array}$ & $\begin{array}{l}\text { Sinistral strike- } \\
\text { slip fault }\end{array}$ & $>0.5$ & $\begin{array}{l}\text { Khalifa et } \\
\text { al.,, } 2018\end{array}$ \\
\hline GBFZ & $\begin{array}{c}\text { Dextral strike- } \\
\text { slip fault }\end{array}$ & $>0.5$ & This study \\
\hline
\end{tabular}

Calculated slip rate of $\sim 0.5 \mathrm{~mm} /$ year along the northern section of GBFZ is in good agreement with other defined uplift rates in Turkey (e.g., Yazıcl et al. 2018, Khalifa et al. 2018, this study). Calculations of geomorphic indices shed on lights GBFZ's tectonic evaluation and provide us valuable data to use for further studies.

\section{Acknowledgments}

This study is part of a Ph.D. thesis undertaken by the first author at the Institute of Natural and Applied Sciences, Dokuz Eylül University, Turkey, and is supported by TUBITAK (The Scientific and Technological Research Council of Turkey) with project Number of 117Y190. The authors would like to thank Pınar Gırca from The University of Southern Queensland for English editing.

\section{References}

Aktuğ, B. and Kılıçoğlu, A., 2006. Recent crustal deformation of İzmir, Western Anatolia and surrounding regions as deduced from repeated GPS measurements and strain field. Journal of Geodynamics, 41, 471-484.

Aktuğ, B., Nocquet, J. M., Cingöz, A., Parsons, B., Erkan, Y., England, P., ... and Tekgül, A., 2009. Deformation of western Turkey from a combination of permanent and campaign GPS data: Limits to block-like behavior. Journal of Geophysical Research: Solid 
Earth, 114(B10).

https://doi.org/10.1029/2008JB006000

Aktuğ, B., Ozener, H., Dogru, A., Sabuncu, A., Turgut, B., Halicioglu, K., ... and Havazli, E., 2016. Slip rates and seismic potential on the East Anatolian Fault System using an improved GPS velocity field. Journal of Geodynamics, 94,

$1-12$.

https://doi.org/10.1016/j.jog.2016.01.001

Baize, S., Audin, L., Winter, T., Alvarado, A., Moreno, L.P., Taipe, M., Reyes, P., Kauffmann, P., and Yepes, H., 2015. Paleoseismology and tectonic geomorphology of the Pallatanga fault (Central Ecuador), a major structure of the South-American crust. Geomorphology, 237, 14-28 https://doi.org/10.1016/j.geomorph.2014.02.030

Bull, W.B., 1977a. Tectonic geomorphology of the Mojave Desert, California. U.S. Geological Survey Contract Report 14-0-001-G-394. Office of Earthquakes, Volcanoes, and Engineering, Menlo Park, California, 188.

Bull, W.B. and McFadden, L.D., 1977. Tectonic geomorphology north and south of the Garlock fault, California. In: Doehring, D.O. (Ed.), Geomorphology in Arid Regions. Proceedings of the Eighth Annual Geomorphology Symposium. The State University of New York, Binghamton, NY, 115-138.

Bull, W.B., 2007. Tectonic geomorphology of mountains: a new approach to Paleoseismology. Oxford: Wiley, 328.

Burbank, D.W. and Anderson, R.S., 2001. Tectonic geomorphology. Oxford: Blackwell Science, 247.

Baharvand, S., Pardhan, B. and Soori, S., 2020. Evaluation of active tectonics using geomorphic indices in a mountainous basin of Iran. Earth and Environmental Science Transactions of the Royal Society of Edinburgh, 111(2), 109-117. https://doi.org/10.1017/S1755691020000031

Bozkurt, E. and Sözbilir, H., 2006. Evolution of the largescale active Manisa Fault, southwest Turkey: implications on fault development and regional tectonics. Geodin. Acta 19, 427-453 https://doi.org/10.3166/ga.19.427-453

Cannon, P.J., 1976. Generation of explicit parameters for a quantitative geomorphic study of Mill Creek drainage basin. Oklahoma Geology Notes 36 (1), 316.

Cowgill, E., 2007. Impact of riser reconstructions on the estimation of secular variation in rates of strike-slip faulting: revisiting the Cherchen River site along the
Altyn Tagh Fault, NW China. Earth and Planetary Science Letters 254, 239-255. doi:10.1016/j.epsl.2006.09.015

Cowgill, E., Gold, R.D., Chen, X.H., Wang, X.F., Arrowsmith, J.R., Southon, J., 2009. Low Quaternary slip rate reconciles geodetic and geologic rates along the Altyn Tagh fault, northwestern Tibet. Geology 37, 647-650.

Crupa, W.E., Khan, S.D., Huang J., Khan, A.S. and Kasi, A., 2017. Active tectonic deformation of the western Indian plate boundary: A case study from the Chaman Fault System. Journal of Asian Earth Sciences, 147, 452-468. https://doi.org/10.1016/j.jseaes.2017.08.006

Dehbozorgi, M., Pourkermani, M., Arian, M., Matkan, A.A., Motamedi, H. and Hosseiniasl, A., 2010. Quantitative analysis of the relative tectonic activity in the Sarvestan area, central Zagros, Iran. Geomorphology 121, 329-341.

El Hamdouni, R., Irigaray, C., Fernández, T., Chacón, J., Keller, E.A., 2007. Assessment of relative active tectonics, southwest border of the Sierra Nevada (southern Spain). Geomorphology 96, 150-173.

Emre, Ö. and Barka, A. 2000. Gediz grabeni-Ege Denizi arasının (İzmir yöresi) aktif fayları. Batı Anadolu'nun Depremselliği Sempozyumu, (BADSEM2000), Bildiriler Kitabı, İzmir, 131-132. (in Turkish).

Emre, Ö., Özalp, S., Doğan, A., Özaksoy, V., Yıldırım, C. and Göktaş, F., 2005. İzmir ve yakın çevresinin diri fayları ve deprem potansiyelleri, Jeoloji Etütleri Dairesi, Rapor No:10754. 86 . (in Turkish)

Emre, Ö., Duman., T.Y., Özalp, S., Olgun Ş, Elmacı, H., Şaroğlu, F., Çan, T., 2016. Active fault database of Turkey. Bull Earthq Eng. https://doi.org/10.1007/s10518-016-0041-2

Erkül, F., Helvacı, C. and Sözbilir, H., 2005. Evidence for two episodes of volcanism in the Bigadiç borate basin and tectonic implications for western Turkey. Geological Journal, 40, 1-16.

Eyubagil, E. E., Solak, H. I., Kavak, U. S., Tiryakioğlu, I., Sözbilir, H., Aktuğ, B. and Özkaymak, Ç., 2021. Present-day strike-slip deformation within the southern part of the Izmir-Balıkesir Transfer Zone based on GNSS data and implications for seismic hazard assessment in western Anatolia. Turkish Journal of Earth Sciences, 30(2).

Faghih, A. and Nourbakhsh, A., 2015. Appraisal of relative tectonic activity along the Kazerun Fault Zone, Zagros Mountains, Iran: insight from spatial 
analysis of geomorphic indices. Geological Journal, 50(6), 783-798.

Faghih, A., Nezamzadeh, I. and Kusky, T. M., 2016. Geomorphometric evidence of an active pop-up structure along the sabzpushan fault zone, Zagros mountains, SW Iran. Journal of Earth Science, 27(6), 945-954.

Fu, B., Awata, Y., Du, J., He, W., 2005. Late Quaternary systematic stream offsets caused by repeated large seismic events along the Kunlun fault, northern Tibet. Geomorphology. 71, 278-292.

Fu, B. and Awata, Y., 2007. Displacement and timing of left-lateral faulting in the Kunlun Fault Zone, northern Tibet, inferred from geologic and geomorphic features. Journal of Asian Earth Sciences. 29, 253-265.

Göktaş, F., 2014. Karaburun Yarımadası kuzey kıyı kesiminin Neojen stratigrafisi. 79 Maden Tetkik ve Arama Dergisi. 148, 43-61 (in Turkish).

Gregory, K. J. and Walling, D. E., 1973. Drainage basin form and process. Edward Arnold, London.

Hare, P.W. and Gardner, T.W., 1985. Geomorphic indicators of vertical neotectonism along converging plate margins, Nicoya Peninsula, Costa Rica. In: Morisawa, M., Hack, J.T. (Eds.), Tectonic Geomorphology. Proceedings of the 15th Annual Binghamton Geomorphology Symposium. Allen and Unwin, Boston, 123-134.

Horton, R.E., 1932. Drainage basin characteristics. Trans. Am. Geophys. Union, 13: 350-361

İnci, U., Sözbilir, H., Erkül, F. and Sümer, Ö., 2003. The cause of the earthquakes between the Urla and Balıkesir is a fossil fault. Cumhuriyet Newspaper Science Technic Journal, 848, 6-7 (in Turkish)

Kaya, O., 1979. Ortadoğu Ege çöküntüsünün (Neojen) stratigrafisi ve tektoniği, Türkiye Jeoloji Kurultayı Bülteni, 22, 233-274 (in Turkish)

Kaya, O., Ünay, E., Göktaş, F. and Saraç, G., 2007. Early Miocene stratigraphy of Central West Anatolia, Turkey: implications for the tectonic evolution of the Eastern Aegean area. Geological Journal 42, 85-109.

Keller, E. A. and Pinter, N., 1996. Active tectonic, Earthquickes, Uplift and Landscape". Prentice Hall P. 362.

Keller, E.A. and Pinter, N., 2002. Active Tectonics: Earthquakes, Uplift, and Landscape, 2. Prentice Hall, Upper Saddle River, N.J, 362.
Keller, E. A. and DeVecchio, D. E., 2013. Tectonic geomorphology of active folding and development of transverse drainages. In Treatise on Geomorphology, 129-147. Elsevier Inc.

Khalifa, A., Çakır, Z., Owen, L.A and Kaya, Ş., 2018. Morphotectonic analysis of the East Anatolian Fault, Turkey. Turkish Journal of Earth Sciences, 27. http:/doi:110-126, doi:10.3906/yer-1707-16.

Mahmood, S.A. and Gloaguen, R., 2012. Appraisal of Active Tectonics in Hindu Kush: Insights From DEM Derived Geomorphic Indices and Drainage analysis. Geoscience Frontiers, 3 (4), 407 - 428.

McClusky, S., Balassanian, S., Barka, A., Demir, C., Ergintav, S., Georgiev, I., ... and Kastens, K., 2000. Global Positioning System constraints on plate kinematics and dynamics in the eastern Mediterranean and Caucasus. Journal of Geophysical Research: Solid Earth, 105(B3), 5695-5719.

Marinos, P. and Hoek, E., 2000. GSI: a geologically friendly tool for rock mass strength estimation. In ISRM international symposium. International Society for Rock Mechanics and Rock Engineering.

Nugroho, S.K., Gibson, N.P., de Mooij, E.J., Herman, M.K., Watson, C.A., Kawahara, H. and Merritt, S.R., 2020. Detection of Fe $\mathrm{i}$ Emission in the Dayside Spectrum of WASP-33b. The Astrophysical Journal Letters, 898(2), L31.

Nyst, M., and Thatcher, W., 2004. New constraints on the active tectonic deformation of the Aegean. Journal of Geophysical Research: Solid Earth, 109(B11).

Ocakoğlu, N., Demirbağ, E. and Kuşçu, i., 2005. Neotectonic structures in İmir Gulf and surrounding regions (western Turkey): Evidences of strike-slip faulting with compression in the Aegean extensional regime. Marine Geology, 219, 155-171.

Omidali, M., Arian, M., and Sorbi, A. , 2015. Neotectonics of Boroujerd Area, SW Iran by Index of Active Tectonics. Open Journal of Geology, 5(05), 309.

Owen, A. W., Armstrong, H. A. and Floyd, J. D., 1999. Rare earth element geochemistry of upper Ordovician cherts from the Southern Uplands of Scotland. Journal of the Geological Society, 156(1), 191-204.

Özkaymak, Ç. and Sözbilir, H., 2008. Stratigraphic and structural evidence for fault reactivation: the active Manisa fault zone, western Anatolia. Turkish Journal of Earth Sciences, 17, 615-635. 
Özkaymak, Ç. and Sözbilir H., 2012. Tectonic geomorphology of the Spildağı high ranges, Western Anatolia. Geomorphology, 173, 128-140.

Özkaymak, Ç., 2014. Tectonic analysis of the Honaz Fault (western Anatolia) using geomorphic indices and the regional implications. Geodinamica Acta, 27(2-3), 110-129.

Özsayın, E., 2016. Relative tectonic activity assessment of the Çameli Basin, Western Anatolia, using geomorphic indices. Geodinamica Acta, 28(4), 241253.

Papazachos, B.C. and Papazachou, C.B., 1997. The earthquakes of Greece. Ziti Publishing, 304.

Patton, P.C., 1988. Drainage basinmorphometry and floods. In: Baker VR, KochelRC, Patton PC (ed.) Flood geomorphology, 51-65.

Pike, R.J. and Wilson, S.E., 1971. Elevation Relief Ratio, Hypsometric Integral and Geomorphic Areaaltitude Analysis. Geological Society of America Bulletin, 62 , 1079 - 1084

Ramírez-Herrera, M.T., 1998. Geomorphic assessment of active tectonics in the Acambay Graben, Mexican volcanic belt. Earth Surface Processes Landforms, 23, 317-332.

Rana, N., Singh, S., Sundriyal, Y. P., Rawat, G. S., and Juyal, N., 2016. Interpreting the geomorphometric indices for neotectonic implications: An example of Alaknanda valley, Garhwal Himalaya, India. Journal of Earth System Science, 125(4), 841-854.

Reilinger, R. E., Mcclusky, S. C., Oral, M. B., King, W. and Toksöz, M. N., 1997. Global positioning system measurements of present crustal movements in the Arabia- Africa-Eurasia plate collision zone. J.Geophys. Res., 102, 9983-9999.

Reilinger, R., McClusky, S., Vernant, P., Lawrence, S., Ergintav, S., Cakmak, R., ... and Nadariya, M., 2006. GPS constraints on continental deformation in the Africa-Arabia-Eurasia continental collision zone and implications for the dynamics of plate interactions. Journal of Geophysical Research: Solid Earth, 111(B5).

Ring, U., Susanne, L. and Matthias, B., 1999. Structural analysis of a complex nappe sequence and late orogenic basins from the Aegean Island of Samos, Greece. Journal of Structural Geology, 21, 15751601.

Rockwell, T.K., Keller, E.A. and Johnson, D.L., 1984. Tectonic geomorphology of alluvial fans and mountain fronts near Ventura, California. In: Morisawa, M. (Ed.), Tectonic Geomorphology. Proceedings of the 15th Annual Geomorphology Symposium. Allen and Unwin Publishers, Boston, MA, 183-207.

Saber, R., Çağlayan A. and Işık V., 2018. Relative tectonic activity assessment and kinematic analysis of the North Bozgush fault zone, NW Iran. Journal of Asian Earth Sciences, 164, 219-236.

Sağlam, S.,A. and Düzgün, M., 2017. Başkale fay zonunun tektonik jeomorfolojisi, Maden Tetkik ve Arama Dergisi , 155, 33-47 (in Turkish).

Selim, H.,H., Tüysüz, O., Karakaş, A. and Taş, K.Ü., 2013. Morphotectonic Evidence from The Southern Branch of The North Anatolian Fault (NAF) and Basins of The South Marmara Sub-Region, NW Turkey. Quaternary International, 292, 176 - 192.

Silva, P.G., Goy, J.L., Zazo, C. and Bardají, T., 2003. Faultgenerated mountain fronts in southeast Spain: geomorphologic assessment of tectonic and seismic activity. Geomorphology, 50, 203-225.

Softa, M., Emre, T., Sözbilir, H., Spencer, J. Q., and Turan, M., 2018. Geomorphic evidence for active tectonic deformation in the coastal part of Eastern Black Sea, Eastern Pontides, Turkey. Geodinamica Acta, 30(1), 249-264.

Sözbilir, H., Erkül, F. and Sümer, Ö., 2003a. Gümüldür (İzmir) ve Bigadiç (Balıkesir) arasında uzanan Miyosen sonrası yaşlı KD-Doğrultulu accommodation zonuna ait saha verileri, Batı Anadolu [Field evidence for post-Miocene NE-trending accomodation zone lying between Gümüldür (İzmir) and Bigadiç (Balıkesir), west Anatolia]. Geological Congress of Turkey, Ankara, Abstracts, 85-86.

Sözbilir, H., Sümer, Ö., Uzel, B., Ersoy, Y., Erkul, F., İnci, U. and Helvacı, C., 2005. İmir'deki Deprem Dizilerinin Nedeni: faylardaki çiçek yapısı. Cumhuriyet Bilim Teknik Dergisi Deprem Araştırmaları, 976, 1819. (in Turkish)

Sözbilir, H., Sümer, Ö., Uzel, B., Özkaymak, Ç., Ersoy, Y. Erkül, F., İnci, U. and Helvacl, C., 2007. Batı Anadolu'da İzmir-Balıkesir transfer zonu içinde kalan aktif doğrultu-atımlı faylarla sınırlı havzaların jeolojik özellikleri [Geological features of basins bordered by active strike-slip faults that located in the izmirBalıkesir transfer zone, western Anatolia]. 11th Meeting of Active Tectonics Research Group, Abstracts, 42 (in Turkish).

Sözbilir, H., Sümer, Ö., Uzel, B., Ersoy, Y., Erkül, F., İnci, U., Helvacı, C. and Özkaymak, Ç., 2009. 17-20 Ekim 
2005 Sığacık Körfezi (İzmir) depremlerinin sismik jeomorfolojisi ve bölgedeki gerilme alanları ile ilişkisi, Batı Anadolu. Türkiye Jeoloji Bülteni, 52 (2), 217-238. (in Turkish).

Sözbilir, H., Sarı, B., Uzel, B., Sümer, Ö. and Akkiraz, S., 2011. Tectonic implications of transtensional supradetachment basin development in an extension-parallel transfer zone: the Kocaçay Basin, Western Anatolia, Turkey. Basin Research, 23, 423448, doi: 10.1111/j.1365-2117.2010.00496.x.

Strahler, A.N., 1952b. Hypsometric (area-altitude) Analysis of Erosional Topography. Geological Society of America Bulletin, 63, 1117 - 1141.

Strahler, A. N., 1964. Part II. Quantitative geomorphology of drainage basins and channel networks. Handbook of Applied Hydrology: McGrawHill, New York, 4-39.

Taxeidis, K., 2003. Study of historical seismicity of the Eastern Aegean Islands. PhD, University of Athens, Greece, 301 (in Greek).

Tarboton, D.G., Bras, R.L., and Rodriguez-Iturbe, I., 1991. On the extraction of channel networks from digital elevation data: Hydrological Processes, 5, 81-100.

Utlu, M., and Özdemir, H., 2018. The Role of Basin Morphometric Features in Flood Output: A Case Study of the Biga River Basin. J. Geog. 36, 49- 62. https://doi.org/10.26650/JGEOG408101

Uzel, B. and Sözbilir, H., 2008. A first record of a strikeslip basin in Western Anatolia and its tectonic implication: The Cumaovası Basin. Turkish Journal of Earth Sciences, 17, 559-591.

Uzel, B., Sözbilir, H., Özkaymak, Ç., Kaymakci, N., Langereis, C.G., 2013. Structural evidence for strikeslip deformation in the İzmir-Balıkesir Transfer Zone and consequences for late Cenozoic evolution of western Anatolia (Turkey). Journal Geodynamics, 65, 94-116.

Uzun, M., 2019. Evaluation of fluvial processes and formation of drainage network with morphometric indices in Dilderesi Basin (Kocaeli). International Journal of Geography and Geography Education (IGGE), 40, 454-477.

Walker, F. and Allen M.B., 2012. Offset rivers, drainage spacing and the record of strike-slip faulting: The Kuh Banan Fault, Iran. Tectonophysics. 530-531, 251-263.

Wells, S. G., Bullard, T. F., Menges, C. M., Drake, P. G., Karas, P. A. and Kelson, K. I., 1988. Regional variations in tectonic geomorphology along a segmented convergent plate boundary, Pacific coast of Costa Rica. Geomorphology, 1, 239-265.

Yazıcı, M., Zabcı, C., Sancar, T. and Natalin, B. A., 2018. The role of intraplate strike-slip faults in shaping the surrounding morphology: The Ovacık Fault (eastern Turkey) as a case study. Geomorphology, 321, 129145.

Yıldırım, C., 2014. Relative tectonic activity assessment of the Tuz Gölü fault zone; Central Anatolia, Turkey. Tectonophysics, 630, 183-192.

\section{Internet References}

1-http:// www.yerbilimleri.mta.gov.tr_(07.05.2021) 